\title{
A Brief Insight into DisinheritanCE ${ }^{1}$
}

\author{
Adam Talanda \& Iveta Talandová
}

Faculty of Law, Palacký University in Olomouc, Czech Republic adam.talanda01@upol.cz; iveta.talandova01@upol.cz

TALANDA, Adam; TALANDOVÁ, Iveta. A Brief Insight into Disinheritance. International and Comparative Law Review, 2016, vol. 16, no. 1, pp. 153-160. DOI: 10.1515/iclr-2016-0011.

\begin{abstract}
Summary: The article briefly introduces current regulation of disinheritance in the Czech Civil Code. Firstly it deals with the notion and purpose of disinheritance, and consequently it describes reasons for disinheritance and ways of disinheritance, highlighting some interpretation difficulties in this field. .
\end{abstract}

Keywords: Disinheritance, deed of disinheritance, mandatory share, forced heir

\section{Introduction}

The institution of disinheritance is regulated in Sections 1646 to 1649 of the Civil Code ${ }^{2}$ and it is the only option for the decedent to deprive the forced heir from his right to mandatory share, by the means of disposition mortis causa. ${ }^{3}$ Disinheritance is understood as the decedent's expression of will, made under conditions stipulated for the creation of a person's will, in which the decedent deprives the forced heir form his mandatory share entirely, or shortens the right to mandatory share. The institution of disinheritance enables the decedents to sanction inappropriate conduct of his descendant, to whom the decedent otherwise would have been obliged by law to bequeath a certain part of his estate or a sum of money. Yet, it is an expression of the principle of autonomy of will as a basic principle of law of inheritance by which the decedent has to have the option to decide what will happen with his assets in case of death, in the manner prescribed by law. It is noteworthy that current law of inheritance stems from the

1 The article is a partial output of the project IGA_PF_2015_025 "Disposition in case of death", Palacký University, Faculty of Law. The article follows from a paper presented at the conference "Olomouc Debates of Young Lawyers 2015", held at Véska on 11-13 September 2015.

2 Act No. 89/2012 Sb., Civil Code, hereinafter referred to as "the Civil Code".

3 As to the forced heir and mandatory share see e.g. BEDNÁŘ, Václav. Nepominutelný dědic. In HAVEL, Bohumil, PIHERA, Vlastimil. Soukromé právo na cestě. Eseje a jiné texty k jubileu Karla Eliáše. Plzeň: Aleš Čeněk, 2010, p. 17-28; HORÁK, Ondřej. Tzv. nepominutelný dědic v novém občanském zákoníku. Právní rozhledy, 2014, Vol. 11, p. 381-386; KOHOUTEK, Jan. Nepominutelný dědic jako účastník řízení o pozůstalosti. Ad Notam, 2015, Vol. 5, p. 3-6. 
principle that disinheritance should not be supported, ${ }^{4}$ therefore disinheritance is possible to apply only for reasons exhaustively defined by law.

\section{Reasons for disinheritance}

The Civil Code enables application of disinheritance only for forced heirs, i.e. children of the decedent or their descendants. ${ }^{5}$ These forced heirs must be mentioned in disposition mortis causa and the decedent must leave them their mandatory share at least, unless the decedent disinherits them for reasons set by law. A decedent may disinherit a forced heir who:

a) failed to provide decedent with the necessary assistance at a time of need,

b) fails to show such genuine interest in the decedent as he should,

c) has been convicted of a criminal offence committed under circumstances which indicate his perverse nature, or

d) permanently leads a dissolute life.

The decedent has the option to disinherit a forced heir even for fulfilling of more than one reason for disinheritance. The reasons for disinheritance, stated in points a), b) and d), are already traditional ones, the interpretation of which has been satisfactorily clarified in legal theory and practice. ${ }^{6}$ The reason for disinheritance stated under c) was newly introduced to the Civil Code and it differs from the previously used, comparable reason for disinheritance, which reads: c) has been sentenced for intentional offence to at least one-year imprisonment. ${ }^{7}$ This reason for disinheritance has been modified for the reason that it too much expanded the option of disinheritance even onto crimes insignificant for family relations, which could tempt the decedent to misusing this reason for disinheritance. ${ }^{8}$ The new formulation requires proving of commitment of the crime under circumstances indicating perverse character of the forced heir, which will require much more exact and complex evidence than was needed according to the previously used regulation. Among others, for the reason that "perverse nature" is

4 Exheredationes non sunt adiuvandae. ELIÂŠ, Karel et al. Nový občanský zákoník s aktualizovanou di̊vodovou zprávou. Ostrava: Sagit, 2012, p. 671.

5 The decedent may exclude also other persons than forced heirs form their lawful claim to inherit, in a simplified way, compared to disinheritance. The decedent has the option to make a so-called negative testament pursuant to Section 1649 of the Civil Code, in which he may order that some of the forced heirs shall receive nothing of his decedent's estate. Further, the decedent has the option to exclude forced heirs from lawful claim by making his disposition in case of death, thereby omitting those persons.

6 For further details see e.g. FIALA, Roman, DRÁPAL, Ljubomír a kol. Občanský zákoník. Komentár. IV. Dédické právo (sections 1475 to 1720). Praha: C. H. Beck, 2015, p. 413-424; SVOBODA, Pavel, KLIČKA, Ondřej. Dédické právo v praxi. Praha: C. H. BECK, 2013, p. 9-18.

7 Section 469a of Act No. 40/1964 Sb., the Civil Code.

8 ELIÁŠ, Karel a kol. Nový občanský zákoník s aktualizovanou di̊vodovou zprávou. Ostrava: Sagit, 2012, p. 671. 
not specifically defined in the Code. ${ }^{9}$ A certain guideline may be aggravating circumstances that are taken into account within criminal proceedings, however, not all of them necessarily prove the perverse character of the disinherited person..$^{10} \mathrm{~A}$ little more complicated will be the use of this reason for disinheritance for the decedent alone, since successful disinheritance will require knowledge of circumstances of the criminal act, which will prove the perverse character of the forced heir, and the mere fact that the forced heir was convicted will not be sufficient. At proceedings relating to decedent's estate, a copy of an entry in the criminal records will not be sufficient to prove the commitment of an offence evidencing the perverse character of the forced heir (as it was possible under the previously used regulation), but the criminal judgement will be needed, if not the whole file. Or, disputes concerning disinheritance will have to be settled in adversarial proceedings, therefore proceedings relating to decedent 's estate will get rather extended. The question remains - whether this regulation represents a move forward. ${ }^{11}$

In addition to the four main reasons for disinheritance, the Civil Code in section 1647 introduces a special reason for disinheritance, where a decedent may also disinherit a forced heir whose indebtedness or prodigal acts raise concern that the forced share will not be maintained for the descendants. However, such a prodigal descendant may only be inherited if the decedent bequeaths the descendant's mandatory share to the children of this forced heir, or, if there are none, to their descendants. Thus, this reason for disinheritance may be applied only to descendants who already have children. The sense of this reason for disinheritance is the protection of the forced heir's family from his reckless conduct as concerns property. Overindebtedness of the forced heir is not required in this case, sufficient is such level of indebtedness that justifies the conclusion that the mandatory share will not remain for his descendants. As far as this reason for disinheritance is concerned, it may be difficult to distinguish adequate and reasonable spending of money from profligacy. When the forced heir spends daily sums that are not common for everyone, it could not, without further evidence, be considered prodigal behaviour when spending corresponds with the financial conditions of the forced heir. Similarly, one cannot be considered a prodigal person when his spending beyond income was caused by the circumstances. On the contrary, otherwise casual spending may cause indebtedness to a person with limited financial possibilities. The Insolvency Act may be a certain guideline in

9 Perverse nature of the offender must be judged not only from the viewpoint of general morality but also as concerns whether the specific offence affects the decedent and his family's honour (the one convicted of repeated theft as a recidivist will hardly be able to disinherit his descendant who has been convicted of theft also). ELIÁŠ, Karel et al. Nový občanský zákoník s aktualizovanou di̊vodovou zprávou. Ostrava: Sagit, 2012, p. 672.

10 For details of aggravating circumstances of an offence see Section 42 of Act No. 40/2009 Sb., the Criminal Code.

11 See also SVOBODA, Pavel, KLIČKA, Ondřej. Dédické právo v praxi. Praha: C. H. BECK, 2013, p. 14-15. 
this situation since it defines terms such as insolvency, bankruptcy or imminent bankruptcy. However, each case will have to be judged individually in the practice, taking in account all circumstances that could have affected indebtedness of the particular person.

Also, forced heir may be disinherited for the reason of incapacity to inherit. ${ }^{12}$ Disinheritance for that reason is mainly applied to enable the decedent to get acquainted the other heirs and the judicial commissioner with the circumstances proving incapacity to inherit of the disinherited descendant, which otherwise may not come out. Further, such disinheritance is a clear indicator of the fact that the decedent has not forgiven the incapable heir his conduct. It may come to the situation when the decedent forgives the incapable forced heir his conduct, however, the decedent will want to bequeath less than is the heir's mandatory share. In such a case the decedent may apply incapacity to inherit as the reason for disinheritance.

\section{Ways of disinheritance}

According to Section 1649 par. 1 of the Civil Code, a declaration of disinheritance may be made, or changed or cancelled, in the same manner as making or cancelling a testament. Written form is required as a rule, i.e. an expression of will recorded in the form of private or public instrument. With respect to the possibility to make a testament made with concessions, it is necessary to admit the option to disinherit orally. ${ }^{13}$ In practice, the deed of disinheritance will constitute a part of another disposition mortis causa, in which the decedent determines the heir of his property.

Disinheritance may be made expressly or in silence. Expressed disinheritance is executed so that, in the deed of disinheritance or in another disposition mortis causa, the decedent states that he disinherits the forced heir, i.e. the decedent

12 Grounds for incapacity to inherit are regulated in Sections 1481 to 1483 of the Civil Code. A person incapable to inherit is primarily the one who has committed an intentional offence to the testator or his relatives, and the heir who has committed condemnable action against the decedent 's last will, while the decedent may forgive the heir for his conduct. Further, the Code contains a special provision on incapability to inherit of the spouse who has applied domestic violence towards the testator where a divorce proceeding is in progress on the day of the decedent's death. Finally, incapable to inherit from his child is the parent who has been discharged from parental responsibility for misuse or neglect thereof. The reasons for incapability to inherit, compared to causes for disinheritance, represent a more serious behaviour, for which the offender may be sanctioned by exclusion from the right to inherit, in compliance with the Code, and without the necessity of expression of the decedent's will.

13 As to the form of the testament see Section 1532 et seq. of the Civil Code. It is noteworthy that the provision on private and public instrument may be rather misleading, where each written recording of the testator's will (traditionally quoted is e.g. a testament written on a cuff or on chalkboard) is considered valid testament. See also SVOBODA, Pavel, KLIČKA, Ondřej. Dédické právo v praxi. Praha: C. H. BECK, 2013, p. 57 et seq. 
excludes the heir from his right to mandatory share, completely or partly. It is possible to implicitly disinherit the forced heir the way that the decedent makes a disposition of his property in the case of death wherein he omits the forced heir, bequeathing no mandatory share or a shortened one to him. If the heir who is disinherited implicitly has committed an act that fulfils legitimate cause for disinheritance, he will be considered disinherited implicitly and by law. Even though both explicit and implicit disinheritance may only be made for reasons set by law, the decedent does not have the duty to give the reasons. ${ }^{14}$ The reason for disinheritance has to exist at least at the time of death of the decedent, which give the decedent the option to disinherit in the case that the heir commits inappropriate behaviour, indicated as one of the legal reasons for disinheritance, in the future up to the time of death of the decedent. ${ }^{15}$

Implicit disinheritance or disinheritance without giving reason is a suitable way of disinheritance in a situation when the decedent does not wish the disinherited forced heir to acquire anything of the decedent's estate and, at the same time, the decedent has no interest in defaming that heir before others. A problem of implicit disinheritance and disinheritance without reason may be consequent evidence of the reason for disinheritance in the case that the disinherited forces heir will not acknowledge the disinheritance and will claim his mandatory share, stating that no reason for disinheritance exists. Should other heirs have no closer information of the reasons for disinheritance, the reasons could be hardly proven consequently. Therefore, it is appropriate that the decedent will insure the disinheritance in a certain way, for example by telling the particular cause for disinheritance to some of the heirs or executor of the testament, or by producing an instrument to clarify the reason for disinheritance, which would be referred to in the declaration of disinheritance, stating that the instrument shall be presented to the court in the case that the disinherited will deny the cause for disinheritance. ${ }^{16}$

In proceedings relating to decedent's estate, yet a different reason for disinheritance may be proved than the decedent indicated (or aimed to). Possible dispute over validity of disinheritance will then raise a key question - whether the reason for disinheritance is stated in the declaration of disinheritance or not. If the reason for disinheritance is stated there, an action to determine the rights

14 As a rule, there is no reason for the testator to give grounds for his decision on disinheritance in the case that the causes are known to him and the disinherited descendant [...] If the decedent makes a declaration of disinheritance in the testament, which is a rule, too many people will have access to that information, perhaps long after the causes for disinheritance occurred and-e.g. at conviction of the disinherited for serious offence - fell into oblivion. ELIÁŠ, Karel et al. Nový občanský zákoník s aktualizovanou di̊vodovou zprávou. Ostrava: Sagit, 2012, p. 673.

15 ŠEŠINA, Martin. In ŠVESTKA, Jiří, DVOŘÁK, Jan, FIALA, Josef et al. Občanský zákoník. Komentár. Svazek IV. Praha: Wolters Kluwer, 2014, p. 359.

16 SVOBODA, Pavel, KLIČKA, Ondřej. Dědické právo v praxi. Praha: C. H. Beck, 2013, p. 11. 
to inherit is to be filed by the descendant who insists that he has been disinherited unlawfully. On the contrary, if the reason for disinheritance is not stated, the petition shall be filed by the one who is to inherit instead the disinherited forced heir.

Declaration of disinheritance may be changed or cancelled the same way as it has been established, i.e. the same way as cancellation or change of testament. In practice, a deed with required formal elements may be produced, wherein the decedent indicates that he cancels the previously made deed of disinheritance. Further, the deed of disinheritance may be cancelled by destruction thereof, or release from deposition in the case that the public instrument is deposited at court commissioner. According to Section 1576 of the Civil Code, we may assume that disinheritance can also be revoked implicitly the way that the decedent leaves the deed of disinheritance in validity, but makes a new disposition mortis causa wherein he designates the disinherited forced heir as a true heir, thereby bequeathing the forced heir's entire mandatory share or a part of it. If some parts of dispositions mortis causa are in contradiction, the latter version prevails.

\section{Disputes on disinheritance}

If the decedent applies disinheritance and the forced heir opposes the disinheritance, dispute on disinheritance occurs. Disputes on disinheritance, analogically to disputes on the right to inherit regulated in Sections 168 through170 of Act on special court proceedings, ${ }^{17}$ may be legal disputes and factual disputes. In the first case, factual statements of the participants of the proceeding relating to decedent's estate will be identical, but the participants will not agree on legal determination of the issue. In such a case it is necessary only to settle the contentious legal matter. In the second case, factual statements of the participants contradict and factual issue must be resolved, which cannot be settled in proceedings relating to decedent's estate, which is a non-contentious proceedings.

\subsection{Legal dispute}

Legal dispute occurs in a matter of disinheritance when the disinherited person does not deny his performance of an act, which the testator states as the reason of disinheritance, but the disinherited person insists that the act shall not establish a reason of disinheritance.

Contentious legal issue, in relation to disinheritance, may occur for example when the decedent disinherits the forced heir for the reason that he has committed a criminal offence, under circumstances proving his perverse nature. The disinherited person defences himself, stating that although he has committed the

17 Act No. 292/2013 Sb., On special judicial proceeding. 
offence, he was forced to do so by circumstances and there is nothing in the act to prove his perverse nature.

In this case, the contentious issue is based on different legal determination of otherwise non-contentious situation as concerns the facts. ${ }^{18}$ Notary as a court commissioner proceeds in this case in accordance with Section 169 of the Act on special court proceedings, therefore he is entitled to legally judge the contentious issue and by a consequent resolution to decide which of the participants will be dealt with in the proceedings relating to decedent's estate, and which one's presence in the proceedings will be terminated.. However, this resolution will not solve the issue of disinheritance definitely. It is only a decision substantial for further course of the proceedings, as it determines the participants of the proceedings. However, if appeal against the resolution is filed, the proceedings relating to decedent's estate cannot be continued and completed until the court decides the remedial measure. ${ }^{19}$ Further, law explicitly sets forth that the right to inherit of the person whose participation at the proceeding has been terminated shall not extinguish, the right is only not taken in account at the proceedings.

\subsection{Factual dispute}

Different situation occurs when the disinherited forced heir defends himself, insisting that the statements in the declaration of disinheritance are not true. In such a case they are contentious facts that cannot be solved in the proceedings relating to decedent's estate, and contentious proceedings will have to be conducted. Filing the petition and commencement of the contentious proceedings is ruled by section 170 of the Act on special court proceedings. ${ }^{20}$ A period to file a petition will be determined, and it must not be shorter than two months. After settlement of the dispute, participant of the proceedings relating to decedent 's estate will be the one who won the contentious proceedings. If the relevant participant fails to file a petition within the stated period, it shall be deemed that the dispute was resolved to his detriment, and the court commissioner will terminate his participation in the proceedings relating to decedent's estate.

Contentious fact, related to disinheritance, may occur for example when the decedent disinherits his descendant due to his failure to show such a true interest as he should do. The disinherited person defends himself, insisting that the statement contained in the declaration of disinheritance is not true since he tried to

18 SVOBODA, Pavel, KLIČKA, Ondřej. Dédické právo v praxi. Praha: C. H. Beck, 2013, p. 242.

19 SVOBODA, Karel et al. Zákon o zvláštních ř́zeních soudních. Komentář. Praha: C. H. Beck, 2015, p. 347.

20 As a rule, Section 1673 of the Civil Code sets forth who files the petition, if the disinherited person or the one who would inherit instead of him. Decisive is if the reason for disinheritance has been specified: if so, the petition is to be filed by the disinherited person. If the reason for disinheritance has not been specified, the petition should be filed by the person who would inherit instead of the disinherited person. 
contact the decedent several times a year, but the decedent always declined any communication with the disinherited. ${ }^{21}$

\section{Conclusion}

Current regulation of disinheritance in the Civil Code balances the statutory duty of the decedent to bequeath a mandatory share of his property to forced heirs. By disinheritance, the decedent has the option to sanction an inappropriate conduct of the forced heir by excluding the heir from the mandatory share of inheritance or by shortening the heir's mandatory share. At the same time, current Civil Code pursues the principle that disinheritance should not be supported, therefore reasons for disinheritance are exhaustively enumerated by law. The reasons represent a serious breach of moral rules that may be sanctioned by disinheritance. However, interpretation of some of the reasons for disinheritance may cause a problem, both from the point of view of ordinary decedent and legal practice.

21 The interest in the decedent, which should be shown by the descendant, is necessary to judge with respect to the circumstances of the specific case; if the fact that the descendant permanently fails to show true interest in the decedent is a consequence of the fact that the decedent fails to show interest in the descendant. There cannot be concluded, without further evidence, that the descendant's failure to show an interest could have been the reason for disinheritance thereof. Supreme Court judgment of November 27, 2007, file No. 21 Cdo 3435/2006. 